This item was submitted to Loughborough's Research Repository by the author.

Items in Figshare are protected by copyright, with all rights reserved, unless otherwise indicated.

\title{
Pro-poor concessions for sustainable water services
}

PLEASE CITE THE PUBLISHED VERSION

PUBLISHER

(C) Thomas Telford Publishing

LICENCE

CC BY-NC-ND 4.0

\section{REPOSITORY RECORD}

Sohail, M., Jonathan S. Bateman, Andrew P. Cotton, and R.A. Reed. 2019. "Pro-poor Concessions for Sustainable Water Services". figshare. https://hdl.handle.net/2134/3886. 
This item was submitted to Loughborough's Institutional Repository (https://dspace.lboro.ac.uk/) by the author and is made available under the following Creative Commons Licence conditions.

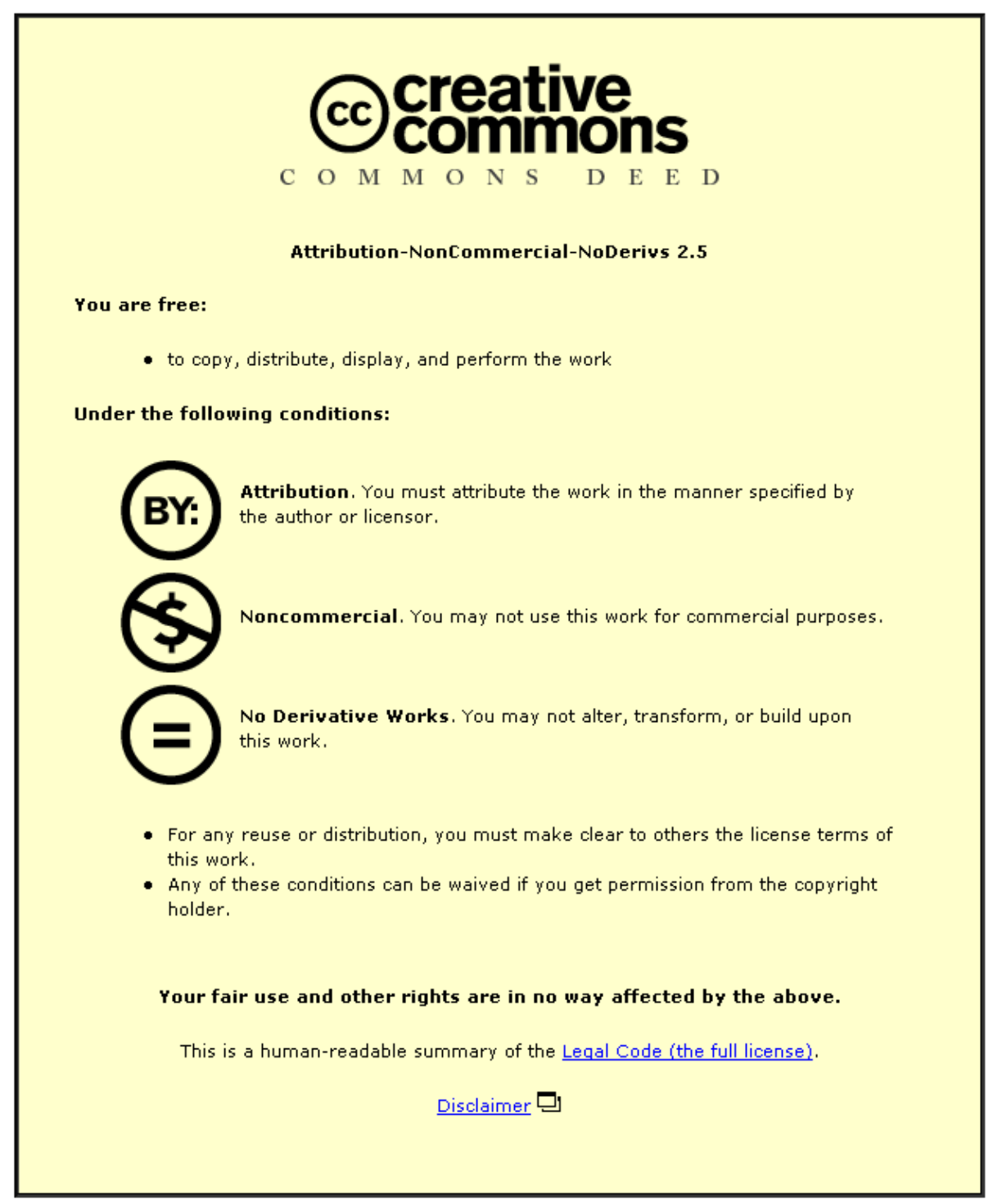

For the full text of this licence, please go to: http://creativecommons.org/licenses/by-nc-nd/2.5/ 


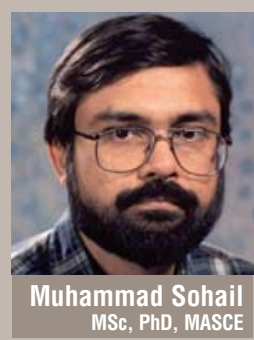

is senior research manager at Loughborough University's Water, Engineering and Development Centre

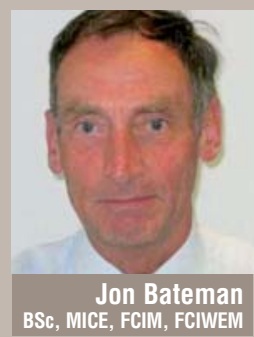

is a director at Halcrow

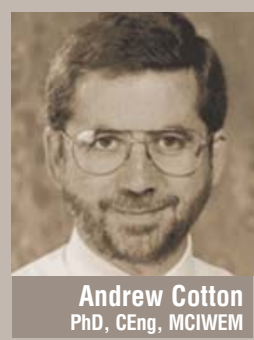

is senior programme manager at Loughborough University's Water, Engineering and Development Centre

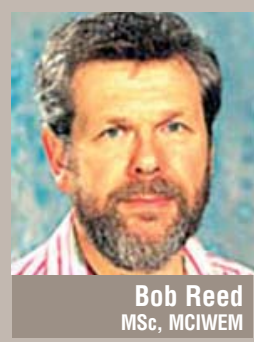

is senior programme manager at Loughborough University's Water, Engineering and Development Centre

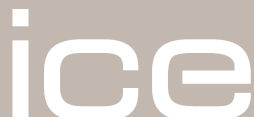

\section{Pro-poor concessions for sustainable water services}

Most of the billions of people without drinking water or sanitation are very poor. While private-sector companies are becoming increasingly involved with infrastructure provision in developing countries, their contracts for water and sanitation services tend to forget the social aspects of providing services to poor people. As such, public-private partnerships in particularly poor countries are unlikely to be sustainable in the longer term and UN targets for improvements will fail to be met. Based on a four-year research project in Asia, Africa and Latin America, this paper explains how concession contracts need to be more suited to the needs, resources and aspirations of local impoverished communities - in other words, to be more pro-poor.

One factor that contributes to making people poor is the lack of an adequate water supply and sanitation. More than 3 billion people in developing countries lack sanitation and more than a billion lack basic drinking water, causing poor quality of life, ill health and less productive nations. Most of the unserved citizens live in informal settlements in Asia, Africa and Latin
America (Fig. 1 and Table 1). ${ }^{1}$

Poor households often spend a high proportion of their incomes and incur substantial indirect and direct costs in terms of both money and time to obtain water from distant sources of water or through private vendors. ${ }^{3-9}$ The problems of access to water and sanitation services as well as the quality of these services

Table 1. Poverty and access to water supply and sanitation by global region. Most of the 1.2 billion people without safe drinking water live on less than US\$1 a day

\begin{tabular}{|c|c|c|c|c|}
\hline Poverty indicator & $\begin{array}{l}\text { East Asia and } \\
\text { the Pacific: } \% \text { of } \\
\text { population }\end{array}$ & $\begin{array}{l}\text { Sub-Saharan } \\
\text { Africa: } \% \text { of } \\
\text { population }\end{array}$ & $\begin{array}{l}\text { Latin America and } \\
\text { the Caribbean: } \% \text { of } \\
\text { population }\end{array}$ & $\begin{array}{l}\text { Global } \\
\text { total: billion } \\
\text { people }\end{array}$ \\
\hline $\begin{array}{l}\text { Living on less than } \\
\text { US\$I a day }\end{array}$ & $23 \cdot 7$ & $29 \cdot 3$ & $5 \cdot 1$ & $1 \cdot 1$ \\
\hline $\begin{array}{l}\text { Without access to } \\
\text { improved water } \\
\text { source in } 2000\end{array}$ & $41 \cdot 4$ & $24 \cdot 9$ & 6.6 & $1 \cdot 2$ \\
\hline $\begin{array}{l}\text { Without access to } \\
\text { adequate sanitation } \\
\text { in } 2000\end{array}$ & 41.5 & $12 \cdot 4$ & $5 \cdot 0$ & $2 \cdot 7$ \\
\hline
\end{tabular}

Source: United Nations Development Programme's Human Development Report $2004^{2}$ 


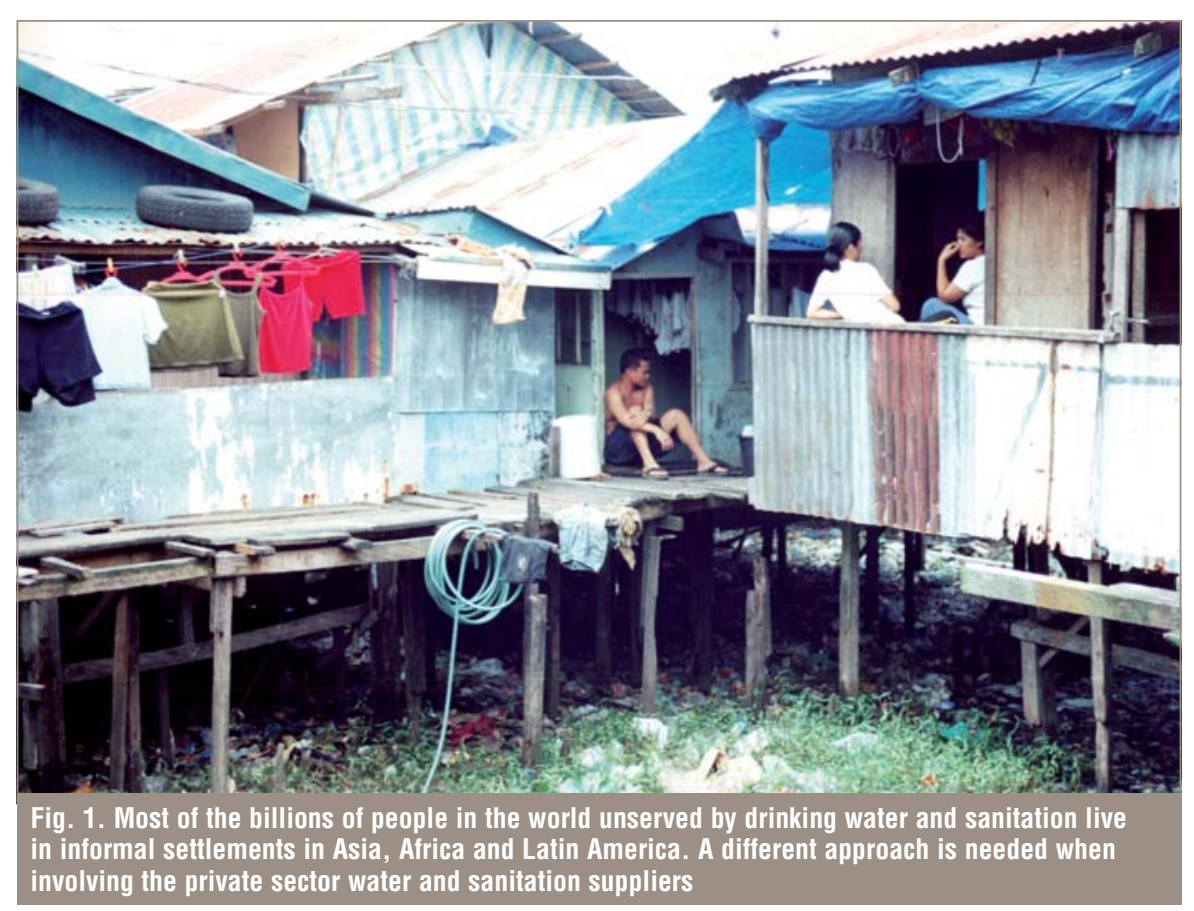

has been recognised, and, under UN Millennium Development Goal 7 there is global consensus to increase water and sanitation coverage by the year 2015 to at least half the number of people not covered in 2000.

However, the public sector in many developing countries has neither the institutional nor the financial capacity necessary to meet those targets. ${ }^{10}$ Government initiatives for improving the infrastructure and delivery of services are hindered by financial constraints, perceptions about limited revenue enhancements from investments for extending services to the poor, limited understanding of the problems and possible solutions, and limited incentives for water utilities (public or private) to address these problems. ${ }^{11}$

Over the past few years, practical self-help and non-government organisation initiatives along with some public utility and private provider programmes have contributed to understanding actions that can be effective in improving access and services for the poor. ${ }^{12,13}$ Partly as a consequence, the last decade has seen a rise in private sector involvement in developing countries. In the specific context of private sector participation, the question is: how can contracts be made pro-poor?

This paper draws upon a four-year research project undertaken in Asia, Africa and Latin America, including fieldwork in the Philippines, Indonesia, South Africa, Morocco, Argentina and Bolivia, ${ }^{14,15}$ and also on the experience of the authors. It argues that regardless of the overall general performance of public-private partnership contracts, they rarely focus on the social aspects of provision of water and sanitation serv- ices to marginalised populations. Hence, without significant modification, such contracts have not and will not address the global agenda directly culminating in the Millennium Development Goals.

\section{Private sector participation}

Experience of private sector involvement in developing countries, especially in the water and sanitation sectors indicates that private sector participation itself does not bring solutions, but rather resources, finance and a specific approach to the delivery of urban services. Experience of the past few years shows that most cases of more successful public-private partnerships have been introduced through contractual renegotiations some years after the original arrangement started.

Forms of private sector participation in the water sector

The public-private partnership contract (or agreement) is most often between a municipal, state or national public authority and a private sector operator or investor. Private sector participation in the water sector ranges from service contracts, through management, lease and concession contracts and in a few cases divestiture. ${ }^{16-22}$

As the development of private sector participation becomes more sophisticated, arrangements are frequently hybrids of two or more of these standard solutions. The provisions that need to be made to improve access and services to the poor could to some extent apply in any private sector participation model or hybrid.

\section{The institutional context}

When water sector, private sector, participation is introduced, there is seldom a water sector institutional and legal framework and, even where it exists, shortcomings in either the framework or the process can limit the extent to which private sector participation attains its objectives. ${ }^{23-26}$ Institutional and legal structures that have inadequate provisions to deal with land tenure, administrative structures, representation, health and social security make solutions more difficult.

A coherent set of legislation (ideally a 'Water Act') to define the roles and relationships of the numerous institutions and stakeholders concerned clearly can create an enabling environment that can culminate into a stable policy. ${ }^{27}$ This is very important if the private sector is expected to take serious long-term risks.

\section{Water sector regulation}

The regulation of services and of financing is an important element of the institutional and legal framework. The regulator must ensure that all consumers receive the agreed services, are charged a fair price, and that the operator can make the necessary infrastructure improvements.

Often regulation will be established in parallel with, or following completion of, the private sector participation preparation process. ${ }^{28-31}$ Certain aspects of the water sector that have significant bearing on the nature of regulation and consequently of contract design are ${ }^{32,33}$

\section{- long planning horizons and high capital} investment needs

- poor information about extent and condition of underground assets

- poor information about customer (revenue) base and extent and types of populations not yet served

- high environmental impact and susceptibility to changes in environmental policies

- high social profile as the provider of an essential service.

\section{Concession contracts}

The reason for focussing on the concession case is that this is the most common form that maximises the transfer of responsibility and risks to the private sector. About half of the large private sector participation projects that came about between 1990 and 1997 in developing countries were long-term concession contracts. ${ }^{34}$

\section{The basis for a pro-poor approach}

Private-public partnerships, if looked at as partnerships sharing a common goal for all stakeholders involved, including the poor, re- 
quire a concessional contractual framework that is pro-poor. ${ }^{27,35-38}$ There is not yet the perfect concession contract, but of all the forms of private sector participation, excluding divestiture, the concession is the one in which outputs, rather than means of achievement, are most strongly the core objectives.

In a concession contract, all the necessary duties and powers to operate, invest in the system (including expansion to the poor) and collect revenues are transferred to the private operator, along with the exclusive right to use the sector's existing assets for those purposes. The non-ownership transfer feature is also the most politically saleable option in the developing world. Given the right political climate, experts view concessions as the most desirable vehicles for increased investment and efficiency. ${ }^{39-42}$

A concession contract, if designed correctly, can provide maximum flexibility for improving services without transferring asset ownership to the private sector. ${ }^{39,42-46}$ For a concession contract, therefore, the primary roles of the regulator will be to monitor performance, and to interpret the contract and adjudicate on the adjustments required in response to changes in circumstances. Such regulation should provide the flexibility and adaptability needed to solve the problems of the poor and should be recognised in the overall legal framework for the water sector. Governments in the Philippines, Indonesia, South Africa, Morocco, Argentina and Bolivia have been entering public-private partnerships for enhancing access and quality of water supply and sanitation.

Basis for the review and subsequent analysis Solutions for services improvement must encompass the technical methods available and the organisational and institutional provisions necessary to support them. Successful solutions will be both effective and sustainable. The identification of effective solutions is mainly related to local circumstances, whereas the sustainability of those solutions is more often related to sector-level provisions, including institutional frameworks and mechanisms. The two requirements—effectiveness and sustainability—have to be provided for by the concession contract and by regulatory mechanisms.

Sustainability of effective infrastructure options Public-private partnerships are viable for the different technical options of water supply, sanitation and sewage disposal, including individual house connections, yard tanks, dedicated customer, yard or communal taps, communal standpipes, water kiosks, water vending or water tankers for water supply and full waterborne or condominium sewerage, septic tanks, on-plot latrines or public toilet blocks for sanitation. The factors that have to be considered in identifying effective solutions for a settlement include poverty and affordability of the residents

- socio-cultural beliefs and usage patterns

- local topographic and resource availability

- proximity of infrastructure networks

political environment.

\section{Sector-level success factors}

Sustainability, as determined by provisions at sector level, will depend on

$$
\begin{aligned}
& \text { inclusivity } \\
& \text { feasibility } \\
& \text { bankability. }
\end{aligned}
$$

\section{Inclusivity}

Inclusivity means that solutions must be provided for all of the population, including the poorest, in all locations and of whatever means and circumstances; and that all institutions concerned with development, finance and welfare must be included in the agreement of actions. These factors must be incorporated into legislation, agreements, guarantees and contract provisions. The main factors to be considered for satisfactory solutions are

- effective information

institutional preparation

- operator perceptions and proposals

scope of regulation.

\section{Feasibility}

If local solutions are to be incorporated into a stable contract at the sector level, contractual and institutional mechanisms must be based on a feasible model of development, service levels, costs, revenue security, financing and public subsidy.

Feasibility means a contract design that will convince a private operator that the contract performance requirements can be achieved, that risks are appropriately shared and manageable, and that the operator will be able to achieve its commercial objectives. Some of the key elements are summarised below.

The concession must operate on the basis of adequate income.

- The information base for the utility and the environment in which it is to operate must be sufficient to support the objectives of the concession and must be the basis for pricing.

- The contracted rate of expansion and service improvements must be realistic.

- Business projections must assume that planned levels of service for stated areas will not be changed without commensurate increases in tariffs or other sources of finance.

- The operator must be able to see that the projected revenue stream is dependable. There are three major factors in this respect- the size of the customer base, tariff levels and recourse in the event of non-payment by customers.

\section{Bankability}

In order to attract finance, the complete package of the contract and related legislative provisions, agreements and guarantees must be cohesive and consistent with the feasible project. Assessment of the bankability of a proposed concession will be the concern of all those who expect to finance it or to provide guarantees. These stakeholders will include shareholders in the operator's consortium (or special purpose company), commercial investors and lenders, international funding agencies and government.

Bankability will depend upon the legal, institutional and financial provisions and on the financial feasibility of the contract. These factors should be demonstrated by a complete and consistent package of legislation agreements and guarantees, which will share risks appropriately and reduce the risks of investment to an acceptable level commensurate with the return.

\section{Local-level success factors}

At the local level, success factors can be grouped under the three broad headings of

$$
\begin{aligned}
& \text { functionality } \\
& \text { affordability } \\
& \text { appropriateness. }
\end{aligned}
$$

\section{Functionality}

An effective technical option will need to be functional, as well as affordable and responsive to local conditions. The technical solution must deliver water supply of acceptable quality that is adequately accessible and reliable, and sewage disposal that provides acceptable standards of hygiene and privacy.

The term functionality means the potential for each option to meet the requirements for

water quality, accessibility and reliability hygiene and privacy of sewerage disposal.

\section{Affordability}

Solutions and charges must be affordable, and payment methods must assist consumers in managing their limited financial resources. The main factors to be considered in satisfying the affordability criterion are
minimising costs
- tariff structure, subsidy and credit
- payment methods

willingness to pay.

\section{Appropriateness}

Appropriate solutions must recognise or address conditions in poor areas, including institutional and socio-cultural factors and need to fit 
physical and financial conditions (as above) and the social and institutional circumstances at the local level. These circumstances can be defined as

permanence of community
land tenure
community organisation
secondary providers.

\section{Case studies}

\section{Buenos Aires, Argentina}

A 30-year concession was awarded to Aguas Argentinas in 1993 for water and sanitation provision to almost 10 million people in Buenos Aires. Under the original contract, all consumers shared primary distribution costs, whereas new consumers paid individually for secondary distribution (infrastructure charges) and connections. However, most of the unconnected population had low or middle incomes and the secondary charges were relatively high.

In later renegotiations, the infrastructure charges were spread over all consumers and connection charges were made payable by instalments. In this case, pro-poor measures were introduced through joint efforts of the operator, the community, the municipality and non-government organisations after the contract had been awarded.

\section{Manila East, Philippines}

In 1997, the Government of the Philippines entered into two 25-year concessions. The concession for the east zone was awarded to the Manila Water Company, which established the 'Tubig Para sa Barangay' (Water for the Village) programme. This scheme provides legal connections to poor communities who live in crowded, densely populated areas where it is difficult to install conventional water pipes.

Banks of meters have been installed, to which each household can connect its own flexible pipe (Fig. 2). Alternatively, cluster and bulk meters have been installed. The programme was not envisaged in the original contract, but was agreed by the regulator and concessionaire in response to a perceived need. It serves poor areas including around 400000 consumers, and has increased income to the operator.

\section{La Paz-El Alto, Bolivia}

A 25-year concession was signed in 1997 for La Paz, the administrative capital of Bolivia, and El Alto, a low-income neighbouring town. In order to reduce costs to poor consumers, a pilot project was started in 1998 to identify and test innovative systems to provide water supply and sanitation.

The condominium system uses small diameter, shallow pipes laid at flat gradients in properties, yards or footpaths. Maintenance and control of the system by the operator would be difficult because of access to properties, so responsibility is passed to house owners for the upkeep of services passing through their own properties.

Installation costs are recovered from consumers with instalments paid over five years with no interest. In this case, condominium systems reduced costs to between one-quarter and one-third of the cost of conventional systems. The disadvantage, from an operator's point of view, is that the reliability of service depends on the community using and maintaining the system properly.

\section{Conclusion}

Incorporating pro-poor provisions into a concession contract requires a balance between fulfilling public policy and not compromising the commerciality of the transaction and service delivery. Though the discussion is focussed on a concession contract, it can be applied to other forms of long-term contract such as a lease or a combination lease and management contract.

Concession-type contracts have now been in existence for at least a decade. There are also various styles and conventions emanating from differing parts of the world, and it is important to tailor the product to suit the understanding and expectations of the participants. Bankability is key to successful implementation. What may be acceptable to a concessionaire may not be acceptable to its financier, and this in turn risks failure of the whole process.

An effective concession contract is only the 'front-end' of substantial institutional change. That change will be enshrined in legislation and inter-entity agreements and guarantees. The concession company itself will be formed and will operate under numerous internal agreementsbetween the international operators, shareholders in the special purpose company, financiers, suppliers and constructors. The contract and all other acts, agreements and guarantees must be cohesive and consistent in all respects, including provisions concerning the poor.

The authors have reviewed the conditions necessary to enable a commercially successful concession to also be pro-poor. Two of these conditions are stressed again

- clear definitions of service areas, service targets and technical standards for the poor

- robust arrangements for payment and/or subsidies or other support for services to the poor.

In an environment of inefficient contract enforcement, which exists in most of the developing countries, the onus to make any contract deliver effectively lies on the partners' goodwill and commitment to the objectives of the contract. Collaborative and partnering approaches are the key to a successful running of a concession contract.

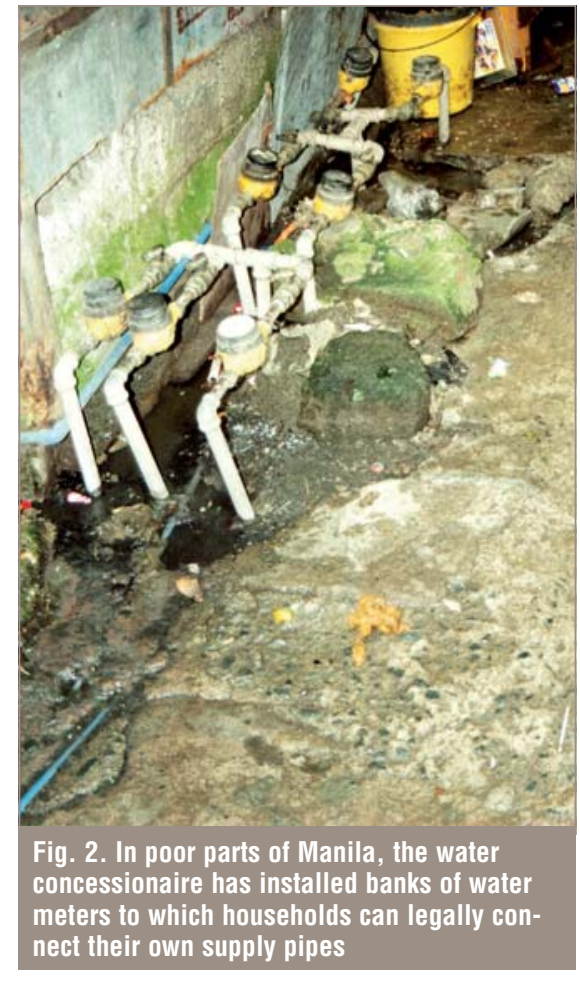

Incorporating<smiles></smiles>
provisions into a concession contract requires a balance between fulfilling public policy and not compromising the commerciality of the transaction 


\section{Acknowledgements}

The authors gratefully acknowledge the many people who have contributed their knowledge, opinions and time to the development of this work. Support from the Department for International Development (DFID) has enabled the authors to undertake this work. The research was a collaborative effort between the Water, Engineering and Development Centre (WEDC), Loughborough University and Halcrow Management Sciences. Thanks to
Sharad Bala Joshi and Dr Sue Cavill for helping us in responding to some of the referee queries. The views expressed here are not necessarily those of DFID, Halcrow or WEDC.

\section{References}

I. United Nations Centre for Human Settlements. Cities in a Globalizing World: Global Report on Human Settlement. EarthScan Press, London, 2001.

2 United Nations Development Programme. Human Development Report 2004: Cultural Liberty in Today's Diverse World. UNDP, New York, 2004.

3. ALTAF M. A. The economics of household response to inadequate water supplies: evidence from Pakistan. Third World Planning Review, 1994, 16, No. I, 4I-53.

4. BRISCOE J. Poverty and water supply: how to move forward. Finance and Development, 1992, 29, 16-19.

5. SOLO T. M. Small-scale entrepreneurs in the urban water and sanitation market. Environment and Urbanization, 1999, II, No. I, II7-131.

6. FASS S. M. Water and poverty: implications for water planning. Water Resources Research, 1993, 29, No. 7, 1975-1981.

7. Calaguas B. Private Sector Participation. WSSCC thematic paper, 1999. Available at: www.wsscc.org.

8. CEPIS/ECLAC. Regulation of the Private Provision of Public Water-Related Services. CEPIS/ECLAC, 1997. Available at: www.cepis.org.pe.

9. CRANE R. Water markets, market reform and the urban poor: results from Jakarta. World Development, 1994, 22, No. 1, 71-83.

10. SATtherwaite D. The Millennium Development Goals and Urban Poverty Reduction: great expectations and nonsense statistics. Environment and Urbanisation, 2003, 15, No. 2, |8|-|9|.

II. WEBB M. and EHRHARDT D. Improving Water Services Through Competition. World Bank, 1998, World Bank Public Policy for the Private Sector Note no. 164.

12. DEVAS N. Reshaping government at the local level in Cambodia: with an example of urban water supply in Battambang. Public Administration and Development, 1996, 16, No. I, 31-4I.

13. ESTACHE A. Making public infrastructure entities commercial. Finance and Development, 1994, 31 , 22-25.

14. SOHAlL M. Public Private Partnerships and Poor: ProPoor; Longer Term (Concessions and Lease) Contract. Water, Engineering and Development Centre, Loughborough University, 2003.

15. SOHAIL M. and CAVILL S. Public Private Partnerships and Poor, Part B-Interim Findings and Case Studies. Water, Engineering and Development Centre, Loughborough University, 2000.

16. SILVA G., TYNAN N. and YILMAZ Y. Private Participation in the Water and Sanitation Sector-Recent Trends. World Bank, 1998, World Bank Public Policy for the Private Sector Note no. 147. Available at: www.ppiaf.org

17. WILKES M. Development of public/private sector frameworks. Proceedings of the 25th Water, Engineering and Development Centre Conference, , . Addis Ababa, 1999, 164-167.
18. SHANKer A. and RODMAN L. Public-private partnerships. Journal of the American Water Works Association, 1996, 88, No. 4, 102-107.

19. RIVERA D. Private Sector Participation in the Water Supply and Wastewater Sector: Lessons from Six Developing Countries. World Bank, Washington D.C., 1996.

20. Roger N. Recent Trends in Private Participation in Infrastructure. World Bank, 1999, World Bank Public Policy for the Private Sector Note no. 196. Available at: www.ppiaf.org

21. BATLEY R. A. Partnerships in Urban Service Provision Are they Working? ID2I Development Research Reporting Service, University of Birmingham International Development Department, Birmingham, 1997.

22. BATLEY R. A. Public-private relationships and performance in service provision. Urban Studies, 1996, 33, Nos 4-5, 723-752.

23. REES J. A. Regulation and private participation in the water and sanitation sector. Natural Resources Forum, 1998, 22, No. 2, 95-105.

24. REIINIERS ]. J. A. M. Organization of PPP projects: the timely prevention of pitfalls. International Journal of Project Management, 1994, I2, No. 3, 137-142.

25. RANASINGHEM. Thoughts on a method to analyse viability of private sector participation in new infrastructure projects in developing countries. Impact Assessment and Project Appraisal, 1998, 16, No. 3, 203-213.

26. BENNETT A. Sustainable public/private partnerships for public service delivery. Natural Resources Forum, 1998, 22, No. 3, 193-199.

27. SOHAIL M. Making Partnering Work for All-A Guideline. Margraf Publishers, Germany, 2003.

28. DRAKEFORD M. Water regulation and pre-payment meters. Journal of Law and Society, 1998, 25, No. 4, 558-602.

29. PRICE Waterhouse. Regulation of Private Monopoly in Developing Countries. Overseas Development Agency, London, 1994

30. WALKER I, VelASQUEZ M. ORDOÑo F and RODRIGUEZ F. Regulation, Organization and Incentives: the Political Economy of Potable Water Services: Case Study of Honduras. Série de documentos de trabajo R-3I4, OCE, IADB, Washington DC, 1997.

31. Bitrán D. and SAEZ R. E. Privatisation and regulation in Chile. In The Chilean Economy: Policy Lessons and Challenges (BOSWORTH B. P., DORNBUSCH R. and LABAN P. (eds)). Brookings, Washington DC, 1994.

32. CROSSLIN R. L. Decision-support methodology for planning and evaluating PPPs. Journal of Urban Planning and Development, 1991, II7, No. I, I5-31.

33. BROOK COWEN P. J. The Private Sector in Water and Sanitation-How to Get Started. World Bank, 1997, World Bank Public Policy for the Private Sector Note no. 126. Available at: www.ppiaf.org

34. UWE H. What now, World Bank? In Global Issue Papers, No. 5: Grab for Water? Different Strategie to Solve the Global Water Crisis. Heinrich Böll Foundation, Berlin, 2003.

35. BROOK COWEN P. J. Getting the Private Sector Involved in Water: What to do in the Poorest of Countries? World Bank, 1997, World Bank Public Policy for the Private Sector Note no. 102. Available at: www. ppiaf.org

36. NiCKson A. Pipe Dreams: Does Privatised Water Offer Poor Urban Neighbourhoods a Better Supply? International Development Department, University of Birmingham, 1997.

37. CheEMA G. S. Services for the urban poor: policy responses in developing countries. In Urban Services in Developing Countries: Public and Private Roles in Urban Development (RONDINELLI D. A. and CHEEMA, G. S. (eds)). Macmillan, London, 1988.

38. RONDINELLI D. A. Increasing the access of the poor to urban services: problems, policy alternatives and organisational choices. Urban Services in Developing Countries: Public and Private Roles in Urban Development (RONDINELLI D. A. and CHeEMA, G. S. (eds)). Macmillan, London, 1988.

39. AMBERT J. C. The concession approach to urban water supply and sanitation in the context of the RDP. Seminar on the Conditions of Contract for DesignBuild and Turnkey Projects, Process Plants and BOT Contracts, Lyonnaise des Eaux, Southern Africa, 1995.

40. Crampes C. and Estache A. Regulating Water Concessions: Lessons from the Buenos Aires Concession. World Bank, 1996, World Bank Public Policy for the Private Sector Note no. 91. Available at: www.ppiaf.org

41. KOMIVES K. and BRooK COWEN P. J. Expanding Water and Sanitation Services to Low-Income Households: the Case of the La Paz-El Alto Concession. World Bank, 1998, World Bank Public Policy for the Private Sector Note no. 178. Available at: www.ppiaf.org

42. NaNKANI H. Testing the Waters - a Phased Approach to a Water Concession in Trinidad and Tobago. World Bank, 1997, World Bank Public Policy for the Private Sector Note no. 103. Available at: www.ppiaf.org

43. JACOBSON C. D.and TARR J. A. Ownership and Financing of Infrastructure: Historical Perspectives. World Bank Policy Working Paper, 1995.

44. Bhattacharyya A., Parker E. and Raffiee K. An examination of the effect of ownership on the relative efficiency of public and private water utilities. Land Economics, 1994, 70, No. 2, 197-209.

45. Bhattacharyya A., Harris T. R., Narayanan R. and RAFFIEE K. Specification and estimation of the effect of ownership on the economic efficiency of the water utilities. Regional Science and Urban Economics, 1995, 25, No. 6, 759-784.

46. TIONG L. K. R. Comparative study of BOT projects. Journal of Management in Engineering, 1995, 6, No. I, $107-122$.

\section{What do you think?}

